\title{
Brexit and the Moon Landing from a Project Complexity Perspective: A Comparative Case Study
}

\author{
Professor Dr. Roland Alter \\ Faculty of Business and Transport Management \\ Heilbronn University of Applied Sciences \\ Max-Planck-Str. 39 \\ D - 74081 Heilbronn, Germany \\ E-mail: roland.alter@hs-heilbronn.de
}

Received: August 9, 2018 Accepted: September 14, 2018 Published: October 15, 2018

doi:10.5296/csbm.v5i2.13484 URL: http://dx.doi.org/10.5296/csbm.v5i2.13484

\begin{abstract}
With the Brexit vote in the United Kingdom on June 23, 2016, a majority of voters decided that the country should leave the European Union, resulting in the formal start of the exiting process on March 29, 2017. During the discussions in the run up to the referendum, the complexity of the undertaking itself was rarely an issue. The subsequent statement by Brexit-Secretary of State David Davis that the complexity of the moon landing would be dwarfed by the complexity of Brexit puts the undertaking into a new perspective and is the starting point for a comparison. Based on the concept of an intrinsic case study with the focus on learning and pattern identification, the comparison is carried out by using a framework of four complexity levels: (1) objective (2) relative (3) subjective and (4) dynamic complexity. The comparison concludes that both projects are characterized by extraordinarily high objective complexity. The difference emerges with respect to the subsequent levels. NASA was aware of the deficiencies and worked systematically to close the gap through professional project management. Brexit, on the other hand, is characterized by widespread ignorance of complexity without a systematic approach to close a dynamically widening complexity gap.
\end{abstract}

Keywords: project management, project complexity, Brexit, NASA, moon landing, case study 


\section{Macrothink}

\section{Introduction}

"First, I believe that this nation should commit itself to achieving the goal, before this decade is out, of landing a man on the moon and returning him safely to the earth" (NASA, 1961). With these words, the American president John F. Kennedy announced on May 25, 1961 the intention of landing on the moon (see fig. 1). It was the starting signal for an unparalleled technological project, which fascinated an entire nation and the whole world when the moon landing was successful on July 20, 1969: "The eagle has landed".

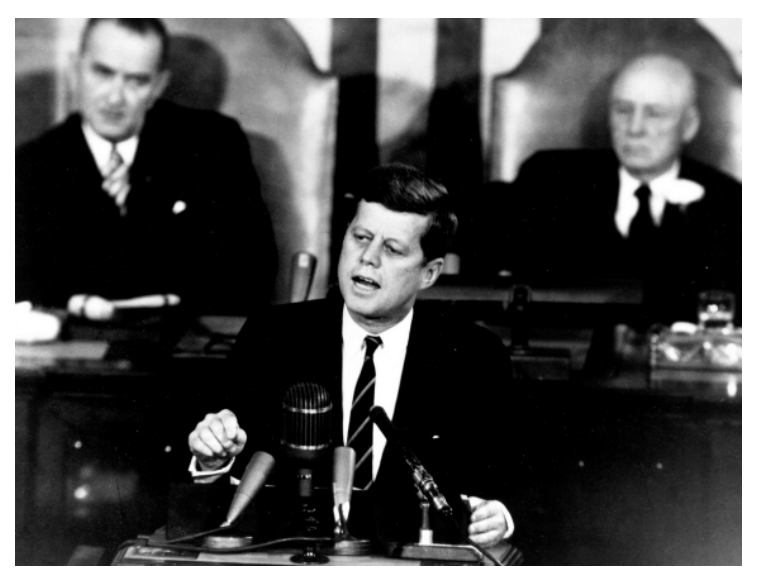

Figure 1. President Kennedy Addresses Congress on May 25, 1961; source: Wikimedia Commons/NASA

More than 50 years after Kennedy began the moon program, another project took off on June 23, 2016. Britons voted in a referendum on whether to remain in or leave the EU ("Brexit"). The ballot paper provided the choice between the two far-reaching alternatives (see figure 2).

\begin{tabular}{|l|}
\hline $\begin{array}{l}\text { Referendum on the United Kingdom's } \\
\text { membership of the European Union }\end{array}$ \\
\hline $\begin{array}{l}\text { Vote only once by putting a cross } \\
\text { your choice }\end{array}$ \\
\hline $\begin{array}{l}\text { Should the United Kingdom remain a member of the } \\
\text { European Union or leave the European Union? }\end{array}$ \\
\hline Remain a member of the European Union \\
\hline Leave the European Union \\
\hline
\end{tabular}

Figure 2. Brexit ballot paper; source: Wikimedia Commons/The Electoral Commission 
With a result of just under $52 \%$ in favour of leaving the EU and just over $48 \%$ in favour of remaining, the decision was made: the majority of the United Kingdom had chosen Brexit (Walker, 2017). As a result of this, the Brexit project was politically authorised and has to be implemented. In legal terms, leaving the EU is triggered by invoking Article 50 of the Treaty of Lisbon. This stipulates negotiations concerning the specific modalities of the departure, against a backdrop of future collaboration. The departure will occur by means of an exit agreement. If no agreement is reached on this, the departure will automatically occur two years after the declaration of intent if the European Council, in agreement with the member state in question, does not unanimously agree to an extension of the deadline (European Union, 2010).

The departure process as per Art. 50 was triggered on March 29, 2017 by a letter from the British government.

About three months later on June 27, 2017, the BBC reported a number of statements made by David Davis, the Secretary of State of the "Department for Exiting the European Union (DExEU)", during a meeting with industry representatives. David Davis gave his view on the complexity of Brexit and drew a comparison with the moon landing: "Half of my task is running a set of projects that make the Nasa moon shot look quite simple" (BBC, 2017).

This statement can also be reformulated as the thesis: "Brexit is far more complex than the moon landing." This raises the question as to how the complexity of Brexit can be compared with the complexity of the moon landing. One, an ongoing socio-political project in the present, and the other a completed technical project of the past that very much defined the 1960s. A comparison on a necessarily abstract level may, on the other hand, provide valuable insights since the moon landing proved to be a successful project, whereas Brexit seems to be struggling.

\section{Research Background}

The research is based on the case study approach, one of the methods of qualitative research. According to Yin, a "case study is an empirical inquiry that investigates a contemporary phenomenon in depth and within its real-life context, especially when the boundaries between phenomenon and context are not clearly evident" (Yin, 2009).

In accordance with Stake (2000), three types of case studies can be distinguished: (1) intrinsic case studies, (2) instrumental case studies and (3) collective case studies.

With an intrinsic case study the emphasis is put on a better understanding of a particular case. The key motivation for the interest in the case is based on its uniqueness and the issues connected with it. "The purpose is not theory building - although at other times the researcher may do just that" (Stake, 2000). Thus the driving force behind an intrinsic case study can be characterized as curiosity, i.e., one of the classic starting points of research. Based on the nature of the findings they may become building blocks for the identification of patterns (Berg \& Lune, 2014) or even the development of theories.

An instrumental case study would see the respective case mainly from the perspective of 
generalization. The case helps to gain an understanding of a specific subject that goes beyond the particular case. The case in question is primarily regarded as representative of a larger group of cases. Whereas an intrinsic case study may lead in the future, with additional research, to theory building, the concept of an instrumental case study puts the emphasis right from the beginning on generalization and theory building. A collective case study extends the instrumental case study of one case to several cases. As before, the cases are seen as representative and better insight is expected to base the research on multiple cases.

The case study of Brexit vs. moon landing can be characterized as a specific application of an intrinsic case study. It expands a singular intrinsic case, to a double case for the purpose of a comparative case study. The cases are unique in their own right, however, they share specific similarities and at the same they show specific differences.

One of the most widely recognized case study researches based on double cases was published by Collins \& Porras (1994). They analyzed a sample of 18 x 2 companies, where within an industry a "visionary company" was set against a "comparison company". By comparing two companies from the same industry, for example Boeing vs. McDonnell Douglas in aerospace, the industry specifics could be excluded from explaining the performance differences. The synthesis of the results from the 18 comparisons identified a management pattern of the visionary companies in relation to the comparison companies.

A case study based comparison of Brexit vs. moon landing can support project management research with respect to project complexity and project success. While there is wide acceptance of a negative relation between project complexity and the probability of project success (Bosch-Rekveldt et. al. 2010; Lou et. al., 2017; Williamson, 2011), one of the impediments for deeper research is the missing agreement on a project complexity framework. The lack of such a framework can be seen as an obstacle for an in depth analysis of the relationship between complexity and project success. The very nature of projects which include the aspect of a certain uniqueness makes it on the other hand highly questionable whether a positive theory of project success will ever be established. If one is to follow the suggestions made by Wynn Jr. \& Williams for Critical Realism (CR) case studies in information systems the focus is on explanation rather than on prediction: "The goal of a CR study is explanation of the mechanisms that generate a certain event, more so than the ability to make predictions about future events or to understand the social/cultural meanings behind the events. [...] An open systems view of the world includes the recognition that regularly occurring events within a complex setting such as a socio technical system are the exception in reality because the effects of available mechanisms are seldom identical across multiple events and contexts" (Wynn Jr. \& Williams, 2012).

The results of such an understanding and explaining of outcomes in dynamic socio-technical systems, may, however, be more usefully applied to future projects that share similar characteristics. Thus the focus should be on understanding patterns that were observed in successful and unsuccessful projects - or projects that are still underway -thereby fostering a continuous learning process. In that sense, case studies represent one of the widely established research methods in the area of project management (Pasian, 2015; Flyvbjerg, 
2011).

Following the portfolio of case study designs by Ridder (table 1), the approach that will be taken for the comparison of Brexit vs. moon landing can be summarized as a social construction of reality. In its specific comparative form it is intended to identify explanatory patterns as the basis for learning.

Table 1. Portfolio of case study research design: differences in underlying elements (Ryder, 2017)

\begin{tabular}{|c|c|c|c|c|}
\hline & \multicolumn{4}{|c|}{ Case study research design } \\
\hline & No theory first & Gaps and holes & $\begin{array}{l}\text { Social } \\
\text { construction }\end{array}$ & No theory first \\
\hline $\begin{array}{l}\text { Representative } \\
\text { scholars }\end{array}$ & Eisenhardt & Yin & Stake & Burawoy \\
\hline The Case & $\begin{array}{l}\text { Research question; } \\
\text { A priori constructs, } \\
\text { variables; } \\
\text { No assumed } \\
\text { relationships }\end{array}$ & $\begin{array}{l}\text { Research question; } \\
\text { Existing theory; } \\
\text { Proposition; } \\
\text { Framework }\end{array}$ & $\begin{array}{l}\text { Curiosity in } \\
\text { the case; } \\
\text { Understanding } \\
\text { of research } \\
\text { issues }\end{array}$ & $\begin{array}{l}\text { Curiosity; } \\
\text { Existing theory; } \\
\text { Anomalies; } \\
\text { Internal } \\
\text { contradictions; } \\
\text { Gaps, silences }\end{array}$ \\
\hline The data & $\begin{array}{l}\text { Theoretical } \\
\text { sampling; } \\
\text { Qualitative data as } \\
\text { the primary choice }\end{array}$ & $\begin{array}{l}\text { Purposeful sampling; } \\
\text { Qualitative data as } \\
\text { the primary choice }\end{array}$ & $\begin{array}{l}\text { Purposive } \\
\text { sampling; } \\
\text { Thick } \\
\text { descriptions; } \\
\text { Holistic } \\
\text { comprehension }\end{array}$ & $\begin{array}{l}\text { Theoretical } \\
\text { sampling; } \\
\text { Dialogue of } \\
\text { observer and } \\
\text { participants }\end{array}$ \\
\hline The analysis & $\begin{array}{l}\text { Emerging constructs } \\
\text { and relationships }\end{array}$ & $\begin{array}{l}\text { Pattern-matching as } \\
\text { a primary choice; } \\
\text { Analytic } \\
\text { generalization }\end{array}$ & $\begin{array}{l}\text { Learning from } \\
\text { the case; } \\
\text { Categorial } \\
\text { aggregation }\end{array}$ & $\begin{array}{l}\text { Social processes; } \\
\text { Structuration; } \\
\text { Reconstruction of } \\
\text { theory }\end{array}$ \\
\hline
\end{tabular}

The research questions on the subject of Brexit vs. moon landing can be summarized as follows:

1) What kind of complexity framework would be appropriate for a comparison of the two projects?

2) How do Brexit and moon landing compare based on the framework?

3) Can we find a pattern helping to explain why the moon landing was successful whereas the Brexit project seems to be struggling? 


\section{Macrothink \\ Case Studies in Business and Management \\ ISSN 2333-3324 \\ 2018, Vol. 5, No. 2}

\section{Systems Life Cycle as a Generic Framework for the Comparison}

Before looking into the aspect of project complexity some major differences between the two projects shall be highlighted, based on the systems life cycle as a generic framework. Projects can be interpreted as part of the life cycle of systems, which is made up of three main phases (Blanchard \& Blyler, 2016):

1) Creation of the system

2) Use of the system

3) Disposal of the system

The moon landing and Brexit exhibit considerable differences in comparison to phases 1 and 2; furthermore, phase 3 can be disregarded. The Apollo program served to create a system which facilitated the landing and safe return of an astronaut.

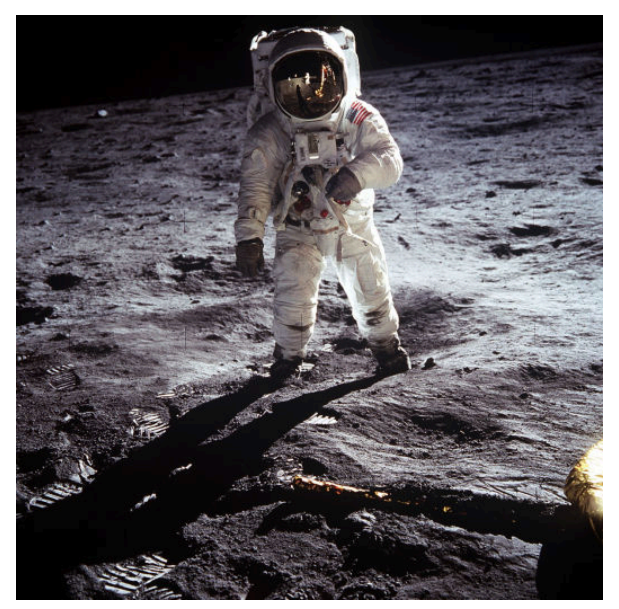

Figure 3. Buzz Aldrin on the Moon (July 21, 1969); source: Wikimedia Commons/NASA

The project objective was fulfilled when the Apollo 11 mission was successfully carried out. After Kennedy's speech, the development of the system for the moon landing took about 8 years, while the actual moon landing itself as part of Apollo 11 took place over just a few days. Apollo 11 began the moon mission on July 16, 1969 with the astronauts Neil Armstrong, Buzz Aldrin and Michael Collins. The moon landing occurred on July 20, 1969 and the safe return was completed on July 24, 1969 (see fig. 3) (Seamans Jr., 2007; Wood, 2011).

The benefit of the project was not to be found in an operational phase lasting several years. The benefit was in the evidence of the feasibility of the moon landing but also, to a special degree, in the route to get there as a uniting and motivating element: John F. Kennedy stated this important aspect clearly at the beginning of the project, "But in a very real sense, it will not be one man going to the moon - if we make this judgment affirmatively, it will be an entire nation. For all of us must work to put him there" (NASA, 1961). 
Both the moon landing and Brexit go through Phase 1, the system creation. In the case of Brexit, this is "Leave the EU", i.e. the breaking away of the United Kingdom from the European Union. Phase 2, the usage phase, shows the central difference to the moon landing. By leaving the EU in Phase 1, the subsequent Phase 2 should then generate advantages, essentially lasting over many years and outweighing the possible disadvantages. These future advantages and disadvantages can be of a political and/or economic nature, with no consensus being reached about the nature and extent of the effects or their benefit assessment.

Based on the referendum, $52 \%$ of the voters were of the opinion that the expected advantages of Phase 2 would outweigh any possible disadvantages. But $48 \%$ of voters voted to remain in the EU in the referendum. This meant approximately half of the voters were not convinced of the propagated advantages of Phase 2. The legitimation of the project is based on a comparatively slim majority. While the moon landing is connected with the idea of a shared national objective, the Brexit project begins with a divided nation.

The question of the benefits of Phase 2 becomes the mainstay of the entire Brexit project. Will it be possible, as part of the project, to fulfil the expectations of the $52 \%$ Brexit supporters and convince as many of the $48 \%$ Remainers as possible?

The ideal goals of Brexit can be described as follows based on statements by Brexit supporters:

A) Complete liberation from the EU legal system, meaning autonomy, particularly in terms of an immigration cap. ("Sovereignty and limits to immigration", "Take back control")

B) No noteworthy negative economic effects towards the EU. ("Continued full access to the single market")

C) Conclusion of far-reaching free trade agreements with other countries. ("Free trade with the world")

D) Scope for extra national spending due to elimination of EU contribution. ("More money for the UK")

E) Execution of all necessary negotiations within the two-year period as per Art. 50 and no payments to the EU (“Quick divorce, no exit bill”).

\section{Project Complexity and Complexity Levels}

The issue of complexity and in particular of project complexity has been discussed intensively by scholars over the years (Azim, 2010; Bakhshi et. al. 2016; Dunovic et. al., 2013; San Cristóbal, 2017; Vidal \& Marle, 2008). From a generic systems theory point of view, complexity describes the diversity of elements and their relationships (Patzak, 1982), and therefore a structural dimension. Following this school of thought Baccarini defined complexity in his review of project complexity in 1996, as "consisting of many varied interrelated parts and can be operationalised in terms of differentiation and interdependency" (Baccarini, 1996). Expanding on Baccarini's work, Williams adds the 
instability of assumptions and the aspect of uncertainty to the structural complexity (Williams, 1999). In particular Williams builds on the works by Turner \& Cochrane (1993) who define uncertainty in the two dimensions of uncertainty of goals and uncertainty of methods to arrive at four different types of projects. Following the approach put forth by Williams, project complexity consists of both structural complexity and uncertainty pertaining to goals and methods (see fig. 4).

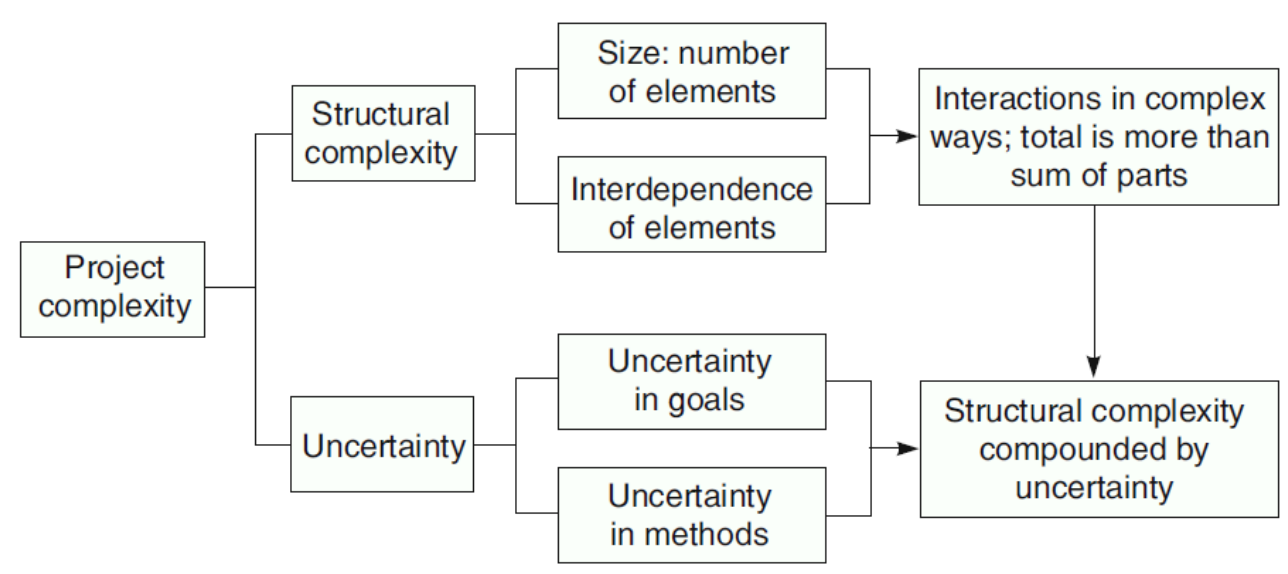

Figure 4. Dimensions of project complexity in accordance with Williams (2002)

As outlined above, projects serve to create or redesign a system. The complexity of a project in terms of structure and uncertainty, therefore, relates to (a) the original state and (b) the target state as well as (c) the necessary transformation process of a system. Uncertainty would include, in addition to ambiguity and fuzziness, the inconsistencies of relevant parameters. Risks, as characterized by magnitude and probability of events which have an undesired influence on achieving the goals, also contribute to the complexity of a project. They can affect the underlying system and its behavior over a specific period of time, as well as the project objectives or applicable measures for achieving the project objectives.

The combination of structural complexity and uncertainty, including risks, is to be understood as "objective complexity". The term objective does not reflect the assumption that an absolute objectivity may be achievable but is based on the concept of reasonably complete information as outlined in the definition of complexity by Edmonds: "Complexity is that property of a model which makes it difficult to formulate its overall behaviour in a given language, even when given reasonably complete information about its atomic components and their interrelations" (Edmonds, 1999).

The main characteristic of objective complexity is the focus on the properties of the project. The objective complexity would provide insights into what seems to be necessary to reach the target state of the system, including sometimes the necessity to clarify the objectives and the starting point. It would also include, based on "reasonably complete information", the understanding of known unknowns. 


\section{Macrothink}

The concept of objective complexity does, however, not consider the capabilities of an organization to handle complexity in the sense of understanding the original state, the target state and the necessary process of systems transformation, including its execution. While building a skyscraper with 50 storeys has a higher objective complexity than building a single family house of 150 square meters, different organizations will match up differently in relation to this complexity. Based on experience and available resources the skyscraper may be a typical business undertaking for one company whereas it will far outstretch the current capabilities of another company. Project complexity in that sense goes beyond the property features of the project system. It also describes the ability of an organization to achieve the target state at all, specifically within a defined financial framework and time frame. It is the comparison of "objective complexity" and the abilities of an organization to manage the project that lead to the "relative complexity".

An essential part of the bid/no-bid process in companies deals with the evaluation of the relative complexity (Kumar, 2016; Shokri-Ghasabeh et. al., 2003). A lack of capabilities to handle a project does, however, not necessarily lead to the rejection of a project. An organization may decide to take on a project that exceeds its current complexity handling capabilities if it has an understanding on how it intends to close the gap. Evaluating the relative complexity requires, similar to the objective complexity, the assumption of reasonably complete information.

However, organizations are not always able to or do not always want to acknowledge the "relative complexity" of a project. This can lead to considerable problems due to over-optimism; the assessment of the "subjective complexity" is often skewed. The delta between the relative complexity and the subjective (=perceived) complexity may result from inability or from unwillingness of understanding. In extreme cases the information is intentionally distorted: the relative complexity may be well understood, but for personal reasons another picture is portrayed to the outside world. The issue of a bias with respect to what is called here "subjective complexity" has been at the heart of the findings by Flyvbjerg (2005) and Flyvbjerg et al. (2003) on public megaprojects, which they characterized as an anatomy of ambition and deception. Flyvbjerg states: "Which large projects get built? Those for which proponents best succeed in designing - deliberately or not - a fantasy world of underestimated costs, overestimated revenues, overall local development effects, and underestimated environmental impacts" (Flyvbjerg, 2005).

Since the relative complexity covers the objective complexity and the capabilities of an organization to deal with it, the bias as expressed by a skewed subjective complexity can relate to either one or both of theses areas: The bias can be displayed by a wrong understanding of the objective complexity ("the job that needs to be done and the objectives that will be achieved with it") and/or a wrong understanding of the organization's capabilities. The concept of a skewed subjective complexity is depicted in fig. 5 . 


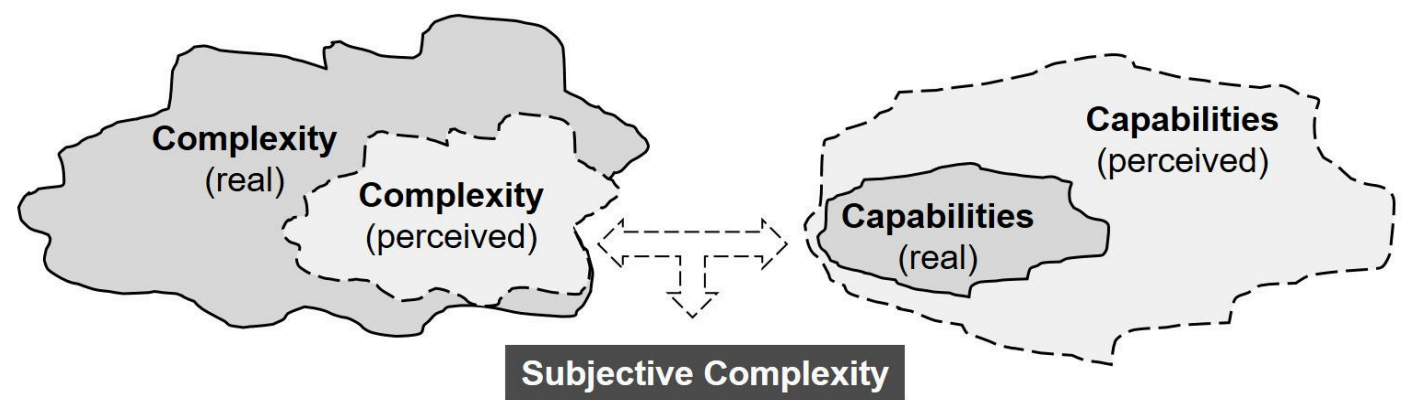

Figure 5. Subjective complexity

In addition to the outlined three complexity levels of objective, relative and subjective complexity it is necessary to take the dynamic character of the phenomenon into account: complexity has a temporal dimension (Oswald, Köhler \& Schmitt, 2018). "Dynamic complexity" describes how the complexity of the three levels develops over the course of the project: "[...] the concept of dynamic complexity addresses the unpredictable situations and emergent events that occur over time, which are associated with interactions among components of a system and between the system and its environment" (Brady \& Davies, 2014). In a recent survey article by Bakhshi et. al. (2016) on project complexity the suggested definition of complexity also captures the dynamic aspect: "[...] the authors agreed on defining project complexity as an intricate arrangement of the varied interrelated parts in which the elements can change and evolve constantly with an effect on the project objectives." Objective, relative and subjective complexity are three dimensions or levels that can be evaluated at any given time throughout a project. The dynamic component characterizes how these dimensions develop over time. While it is not uncommon that projects are started without a perfect relative complexity fit, i.e. a gap at the beginning, the dynamic complexity will reveal if an organization is able to close the gap or if it is even widening (Zhu \& Mostafavi, 2017).

The following comparison of Brexit and the moon landing is to be undertaken based on four levels of complexity:

- Level 1: Objective complexity

- Level 2: Relative complexity

- Level 3: Subjective complexity

- Level 4: Dynamic complexity 


\section{Macrothink

\section{Comparison Based on Complexity Levels}

\subsection{Objective Complexity}

Objective complexity addresses the question how the two projects can be viewed in terms of complexity, irrespective of the commissioned organization. To assess the complexity of projects, a variety of concepts have been developed, whose similarity exists in the multi-dimensional approach. Subsequently, complexity is recorded using the characteristics of a variety of differentiated categories. Depending on the concept, the categories can be connected with preformulated characteristics and scales, up to an aggregated complexity indicator. Table 2 outlines four such concepts, which also take into account elements of the other complexity levels in varying degrees.

Table 2. Complexity models/frameworks (Maylor et. al., 2008; Hass, 2009; Bosch-Rekveldt et al., 2011; Public Works and Government Services Canada, 2015)

\begin{tabular}{|c|c|c|c|}
\hline $\begin{array}{l}\text { Complexity } \\
\text { model/framework }\end{array}$ & $\begin{array}{l}\text { Complexity evaluation } \\
\text { approach }\end{array}$ & $\begin{array}{l}\text { Type and number of } \\
\text { indicators; scale }\end{array}$ & Application area \\
\hline $\begin{array}{l}\text { MODeST Model } \\
\text { Maylor et al. (2008) }\end{array}$ & $\begin{array}{l}\text { evaluation based on } \\
\text { categories and underlying } \\
\text { elements; } \\
\text { combination of objective } \\
\text { and relative complexity; } \\
\text { coverage of dynamic } \\
\text { complexity }\end{array}$ & $\begin{array}{l}5 \text { categories (Mission, } \\
\text { Organization, Delivery, } \\
\text { Stakeholders, and Team) } \\
\text { with } 28 \text { elements; } \\
\text { no scales and consolidated } \\
\text { evaluation of complexity }\end{array}$ & $\begin{array}{l}\text { open } \\
\text { (developed with } \\
\text { project managers from } \\
\text { the telecom, defense, } \\
\text { and transport } \\
\text { infrastructure } \\
\text { industry) }\end{array}$ \\
\hline $\begin{array}{l}\text { Project Complexity } \\
\text { Model } \\
\text { Hass (2009) }\end{array}$ & $\begin{array}{l}\text { evaluation based on } \\
\text { categories; combination of } \\
\text { objective and relative } \\
\text { complexity }\end{array}$ & $\begin{array}{l}11 \text { categories; } \\
\text { scale per category (low, } \\
\text { medium, high complexity) } \\
\text { and resulting total } \\
\text { complexity as } \\
\text { low/medium/high }\end{array}$ & primarily IT-projects \\
\hline $\begin{array}{l}\text { TOE-Framework } \\
\text { Bosch-Rekveldt et al. } \\
\text { (2011) }\end{array}$ & $\begin{array}{l}\text { evaluation based on } \\
\text { categories and underlying } \\
\text { elements; combination of } \\
\text { objective and relative } \\
\text { complexity }\end{array}$ & $\begin{array}{l}3 \text { categories: (Technical, } \\
\text { Organizational, } \\
\text { Environment) with } 50 \\
\text { elements; } \\
\text { no scales and consolidated } \\
\text { evaluation of complexity }\end{array}$ & $\begin{array}{l}\text { large } \\
\text { engineering-projects }\end{array}$ \\
\hline $\begin{array}{l}\text { Project Complexity and } \\
\text { Risk Assessment (PCRA) } \\
\text { Public Works and } \\
\text { Government Services } \\
\text { Canada (2015) }\end{array}$ & $\begin{array}{l}\text { evaluation based on } \\
\text { categories and underlying } \\
\text { questions; focus on } \\
\text { objective complexity with } \\
\text { elements of relative } \\
\text { complexity; capabilities of } \\
\text { the organization as such are } \\
\text { covered separately }\end{array}$ & $\begin{array}{l}7 \text { categories with } 64 \\
\text { questions; scale of } 1-5 \\
\text { points per question, } \\
\text { calculation of a summary } \\
\text { score and assignment of } \\
\text { one of four complexity and } \\
\text { risk levels }\end{array}$ & $\begin{array}{l}\text { public projects } \\
\text { (buildings, IT, ...) }\end{array}$ \\
\hline
\end{tabular}


In this context, the "Project Complexity and Risk Assessment Tool (PCRA)" developed by the Canadian government is of particular interest. It is used to evaluate complexity and risks in public projects based on 64 questions in 7 categories leading to a summary score. As well as objective complexity, the PRCRA elements also take into consideration aspects of relative complexity, if individual personnel decisions have already been made for example. On the other hand, the generic suitability of an organization to carry out projects is determined separately as Organizational Project Management Capacity (OCPRA), similar to a maturity model.

Based on the summary score from the 64 questions a project is allocated to one of the four complexity and risk levels. Brexit and the moon landing can be attributed to the highest level ("Transformational") when using this concept: "4. Transformational: this class of projects requires extensive capabilities and may have a dramatic effect on the organization and, potentially, on other organizations. Horizontal (i.e. multi-departmental, multi-agency, or multi-jurisdictional) projects are transformational in nature. Risks associated with these projects often have serious consequences, such as restructuring of the organization, change in senior management, and loss of public reputation" (Public Works and Government Services Canada, 2015).

However, the moon landing and Brexit differ in one key point as transformational projects: NASA aimed at the moon system with its project. A dynamic and yet (largely) deterministic system found in the Earth's orbit. The "landing zone" is clearly enough defined and stable; the complexity is in the development and use of innovative technology to a never before seen extent.

The situation for the United Kingdom is completely different here. The project was authorised by a general referendum and has no clear "landing zone". In addition, it is characterised by negotiations in a dynamic and uncertain environment with a political and legal character. These negotiations are taking place on a tight two year schedule, which began to start when Article 50 was triggered. While NASA was able to set its own milestones for its project, the United Kingdom is having its initial negotiation milestones dictated by the EU. If the project objective could not be achieved by NASA, the reigning American president could have aborted the project on his own authority. On the other hand, aborting the Brexit project would require another referendum. The political complexity of Brexit is far higher than that of the moon landing.

\subsection{Relative Complexity}

The concept of a relative complexity is required in order to consider how suited organizations are to carry out a project: what experiences does an organization have with projects of the respective complexity, what resources (qualitative and quantitative) can be used for the new project?

The understanding of relative complexity is of fundamental importance when it comes to making the right decisions: from the necessary reinforcement of competences and the appropriate risk management to even stopping a project. 
In the case of the moon landing, NASA did not yet have the necessary skills to fulfil the aim of the project in 1961. However, the crucial point was that the foundation of NASA in 1958 served to consolidate the aerospace competences of the USA in order to be able to keep up with the Soviet Union in space in the future. To achieve this, the National Advisory Committee for Aeronautics (NACA), the Jet Propulsion Laboratory des California Institute of Technology, the Army Redstone Arsenal Team and other units were merged into NASA.

From the very beginning, NASA as an organization was motivated to explore space with increasingly complex projects. In 1961, the organization had an organizational foundation to enable it to systematically develop the necessary skills over time and had already formulated demanding objectives for space missions: at this time, NASA was on the "starting blocks". Political commitment was required to finance a mega project, like the moon landing, which would vastly exceed the magnitude of previous projects. With his visionary goal, Kennedy managed to skilfully unite social stakeholder groups (politics, public, academics, industry, military) in their support of the project. The success of the project would be viewed positively by every single group and would be considered a shared national success. This established the prerequisites to build continually on the initially limited skills to achieve the project objective (Seamans Jr., 2007).

While NASA had at least basic skills aligned with its aerospace objectives at the start of the project, this is different for Brexit. The British executive was in no way prepared as the vote for Brexit (= go for the project) was unwanted by the government leaders. The British government under David Cameron, who was responsible for the referendum, made no preparations for a Brexit and, as such, for a project that would be transformational for the entire country.

At the time of the referendum, there existed no specific skills for handling the project complexity of Brexit. For example, since it joined the EU more than 40 years ago, the United Kingdom has not negotiated any trade agreements of its own, meaning it has no relevant specialists to do so. In view of general project management resources, the National Audit Office is observing a very tense situation in the civil service, which is the heart of British bureaucracy. The resource situation is characterised by challenges in implementing the current project portfolio of public projects. In this way, the Government Major Projects Portfolio (September 2015) alone has projects with life-cycle costs of 405 billion GBP (National Audit Office (NAO), 2017).

Prime Minister Cameron, who himself advocated remaining in the EU, tendered his resignation after the Brexit vote. This meant in the immediate aftermath, there was no Brexit plan to be activated nor was the government capable of acting due to the question of succession.

\subsection{Subjective Complexity}

Subjective complexity addresses the question whether an organization assesses the complexity of the project and its own capabilities to deal with it in a realistic way. 
In view of the moon landing project, NASA had a clearly identified understanding of the complexity from the very beginning. This had particular influence on the deadline Kennedy had stated. Instead of the deadline of 1967 originally outlined in Kennedy's speech, this was adjusted to "before this decade is out", providing NASA with valuable time (Collin, 2008). Other points, which demonstrate the understanding of the complexity, are the organizational adjustments of 1961 and 1963 (Seamans Jr., 2008; Nimmen et. al., 1988) and the concept of the gradually incremental missions.

NASA gradually drew nearer to the aim of the moon landing with its individual missions so that Apollo 11 finally fulfilled the project aim. Table 3 highlights the sequence of the manned Mercury, Gemini and Apollo missions and the further development of the skills. In January 1967, the project suffered a serious setback due to the accidental death of the three Apollo 1 astronauts. The accident highlighted considerable weaknesses and was used by NASA to investigate the causes in detail and derive improvements from this. Without the open discussion of the weaknesses and subsequent improvements, later missions would have been highly endangered (Wood, 2011).

Table 3. Manned NASA missions on the way to the moon landing (NASA, 2016; Orloff, 1996). $\mathrm{CSM}=$ Command and Service Module, $\mathrm{LM}=$ Lunar Module

\begin{tabular}{|c|c|c|c|c|c|}
\hline NASA Mission & & Mass & Start Date & Astronauts & Flight \\
\hline Mercury Redstone 3 & & $955 \mathrm{~kg}$ & May 5, 1961 & 1: Shepard & Earth Suborbital \\
\hline Mercury Redstone 4 & & $955 \mathrm{~kg}$ & July 21, 1961 & 1: Grissom & Earth Suborbital \\
\hline Mercury Atlas 6 & & $1,352 \mathrm{~kg}$ & Febr. 20, 1962 & 1: Glenn & Earth Orbiter \\
\hline \multicolumn{6}{|l|}{ Mercury Atlas 7, 8} \\
\hline Mercury Atlas 9 & & $1,361 \mathrm{~kg}$ & May 15,1963 & 1: Cooper & Earth Orbiter \\
\hline Gemini 3 & & $3,237 \mathrm{~kg}$ & March 23, 1965 & 2: Grissom, Young & Earth Orbiter \\
\hline \multicolumn{6}{|l|}{ Gemini 4 - 11} \\
\hline Gemini 12 & & $3,762 \mathrm{~kg}$ & Nov. 11, 1966 & 2: Lovell, Aldrin & Earth Orbiter \\
\hline [Apollo 1 & & & $\begin{array}{c}\text { Accident during } \\
\text { tests; Jan. 27, } 1967\end{array}$ & $\begin{array}{l}\text { 3: Grissom, White, } \\
\text { Chaffee] }\end{array}$ & \\
\hline Apollo 7 & & $14,781 \mathrm{~kg}$ & Oct. 11,1968 & $\begin{array}{l}\text { 3: Schirra, Eisele, } \\
\text { Cunningham }\end{array}$ & Earth Orbiter \\
\hline Apollo 8 & CSM: & $\begin{array}{r}28,817 \mathrm{~kg} \\
+9,027 \mathrm{~kg}\end{array}$ & Dec. 21,1968 & $\begin{array}{l}\text { 3: Borman, Lovell, } \\
\text { Anders }\end{array}$ & Lunar Orbiter \\
\hline Apollo 9 & $\begin{array}{l}\text { CSM: } \\
\text { LM: }\end{array}$ & $\begin{array}{l}26,801 \mathrm{~kg} \\
14,530 \mathrm{~kg}\end{array}$ & March 3, 1969 & $\begin{array}{l}\text { 3: McDivitt, Scott, } \\
\text { Schweikart }\end{array}$ & $\begin{array}{l}\text { Earth Orbiter } \\
\text { (with Lunar } \\
\text { Module) }\end{array}$ \\
\hline Apollo 10 & $\begin{array}{l}\text { CSM: } \\
\text { LM: }\end{array}$ & $\begin{array}{l}28,834 \mathrm{~kg} \\
13,941 \mathrm{~kg}\end{array}$ & May 18, 1969 & $\begin{array}{l}\text { 3: Stafford, Young, } \\
\text { Cernan }\end{array}$ & $\begin{array}{l}\text { Lunar Orbiter } \\
\text { (with Lunar } \\
\text { Module) }\end{array}$ \\
\hline Apollo 11 & $\begin{array}{r}\text { CSM: } \\
\text { LM: }\end{array}$ & $\begin{array}{l}28,801 \mathrm{~kg} \\
15,103 \mathrm{~kg}\end{array}$ & July 16, 1969 & $\begin{array}{l}\text { 3: Armstrong, } \\
\text { Aldrin, Collins }\end{array}$ & Lunar Landing \\
\hline
\end{tabular}




\section{Macrothink}

In comparison with NASA's approach to the moon landing, the Brexit project demonstrates fundamental weaknesses: the objective complexity and subjective perception of Brexit are vastly different to one another. Several of the central Brexit protagonists had no clear understanding of the objective complexity of the project over an extended period of time. In particular, the necessary transformation processes are almost negligently trivialised and the future benefit is idealised. This, in turn, is closely related to the fundamental weaknesses of the entire project: there is not an even roughly unambiguous target system. As there is no target system, no milestone plan can be developed either, as was used by NASA for the moon landing.

Examples of these deficits in the comprehension of the complexity can be highlighted in statements by David Davis, Boris Johnson, Liam Fox and Michael Gove, who can be considered the political minds of Brexit along with UKIP party leader Nigel Farage.

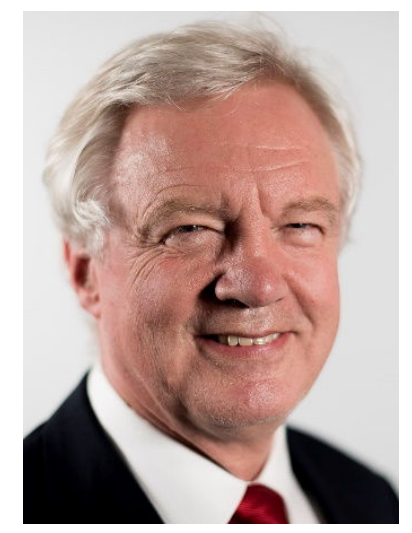

Figure 6. David Davis; source: Wikimedia Commons/Government of UK

A month before the Brexit vote, in May 2016, David Davis (fig. 6) attempted to dispel the concerns about economic consequences of a Brexit: "Indeed the first calling point of the UK's negotiator in the time immediately after Brexit will not be Brussels, it will be Berlin, to strike the deal: absolute access for German cars and industrial goods, in exchange for a sensible deal on everything else. Similar deals would be reached with other key EU nations" (Davis, 2016a).

With this statement, he denied that the negotiations about the new economic relationships would take place with the EU as a block of 27 countries, rather than with individual countries. This was wishful thinking, combined with not wanting to or being unable to understand the EU process.

This can also be seen similarly in view of the negotiations with third states. In July 2016, David Davis proposed these would start after the summer break in September 2016, and on a broad scale at that: "I would expect that the negotiation phase of most of them to be concluded within between 12 and 24 months. So within two years, before the negotiation 
with the EU is likely to be complete, and therefore before anything material has changed, we can negotiate a free trade area massively larger than the EU" (Davis, 2016b). This view of subjective complexity does not bear up to reality in any way: as of September 2017, not a single negotiation has been started, let alone concluded.

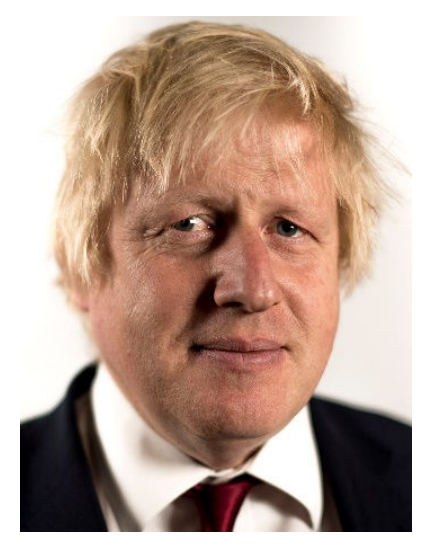

Figure 7. Boris Johnson; source: Wikimedia Commons/Government of UK

Boris Johnson (fig. 7), the former mayor of London, who supported the side of Brexiteers, went as far as to say: "Our policy is having our cake and eating it" (Dunn, 2016). In other words: he wanted to leave the EU but continue to use all the advantages of the Common Market. It was more than predictable that this would face a ferocious backlash from the EU. In the same way, Johnson propagandized that leaving the EU would free up additional funding for the NHS. A red bus bearing the words "We send the EU $£ 350$ million a week [,] let's fund our NHS instead [,] Vote Leave" (Henley, 2016) became the emblem of this statement. Immediately after the referendum, this statement, which also deliberately ignored the reflux of funds provided by the EU, was retracted. This can be seen as an emblem of Brexit promises that were made and unredeemable and the lack of a consistent and realistic target system.

As the "Secretary of State for International Trade", Liam Fox's (fig. 8) task is to conclude new trade agreements with third states. In terms of the Brexit calculation, these agreements must take place (a) with countries, which have no agreement with the EU to date or (b) with which an EU agreement exists, which should ideally be improved but in no way diminished. In July 2016, he was quoted, “[...] Dr Fox claimed numerous non-EU countries had already asked Britain for a trade deal and said he was ,scoping about a dozen free trade deals outside the EU to be ready for when we leave“" (Singh, 2016).

In the sense of subjective complexity, he has long since ignored the fact that it is unrealistic to negotiate with a number of countries simultaneously within the notice period of Article 50 and to come to meaningful conclusions. This is because the desire for a rapid conclusion of trade agreements conflicts the requirement for "deep and comprehensive trade deals" that include the financial sector. The WTO (World Trade Organization) rules, which are viewed as 


\section{Macrothink

a fall-back, primarily address the dismantling of tariff trade barriers, particularly in the form of customs. On the other hand, the significantly more complex issues of non-tariff obstacles are given little consideration. However, these are the obstacles for the financial services sector and, as such, the industry, in which the United Kingdom has its competitive edge and is working to expand. The necessity of extensive and therefore complex, individual agreements is a direct contradiction to the expectation of a simple and rapid Brexit.

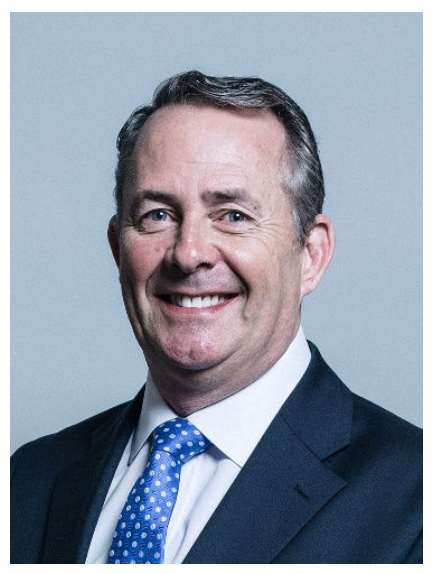

Figure 8. Liam Fox; source: Wikimedia Commons/Government of UK

In September 2017, Liam Fox revealed that the simultaneous negotiation of several agreements was a burden on his resources and that priorities had to be set: "Fox said a trade deal with the U.S. was the government's No. 1 priority after leaving the EU, followed by agreements with Australia and then New Zealand, but admitted it would have to wait until an agreement is struck with Brussels first" (McTaque, 2017). In addition, this demonstrated a project dependency, to which the experts had always referred. Only when it is clear what EU market access the United Kingdom will be granted in the future, can negotiations with third states be driven forwards. If EU agreements already exist with these third states, then these will no longer be valid for the United Kingdom from the day of departure. For the time between the departure from the EU and the conclusion of new agreements, there will need to be transitional agreement provisions, further adding to the complexity. 


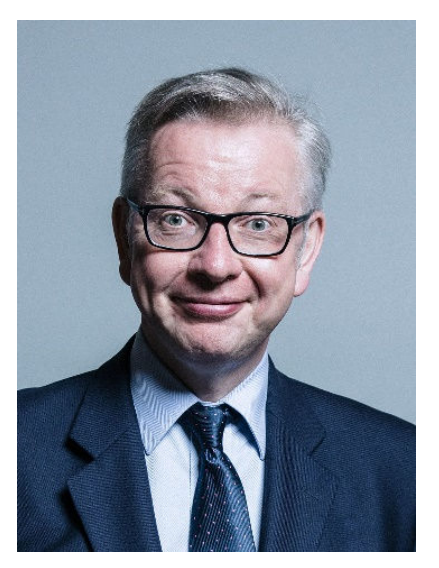

Figure 9. Michael Gove; source: Wikimedia Commons/Government of UK

As one of the central Brexiteers, the phenomenon of trivialising the Brexit complexity could also be seen in Michael Gove's (fig. 9) statements. In his speech about the Brexit referendum in April 2016, he propagandized the concept that the United Kingdom would have all the advantages and levels of freedom on its side if it departed, "The day after we vote to leave we hold all the cards and we can choose the path we want." This continues in his statements about negotiations with the EU, which he views as better day-to-day work: "While there are, of course, some questions up for negotiation which will occupy our highly skilled Foreign Office civil servants, resolving them fully and properly won't be any more complicated or onerous than the day-to-day work they undertake now navigating their way through EU recitals, trialogues and framework directives" (Gove, 2016).

Michael Gove's statements seamlessly include his contempt for expert opinions. During the Brexit discussions, he dismissed the concerns of experts by stating, "people in this country have had enough of experts" (Mance, 2016). No statement is more symptomatic of the serious lack of understanding the complexity, indeed the denial of complexity.

\subsection{Dynamic Complexity}

Dynamic complexity addresses the question how the skills and resources of the organization develop in relation to changes of the underlying complexity of the project.

NASA largely controlled and handled the complexity along the targeted milestone plan. The only exception was the Apollo 1 accident, which was used in all its tragedy to learn important lessons. When new challenges arose, they were ultimately solved on the basis of the massive resource input and led to a number of technical innovations, which continue to have an effect today. From the project management point of view, NASA set milestones in many respects with the processes and structures it introduced: "In 1966 NASA directly employed 36,000 people with another 360,000 people working for 20,000 contractors and 200 universities in 80 countries. [...] The moon landing was a triumph of organisation, of project management and control of a complex socio-technical system" (Parker, 2011). 


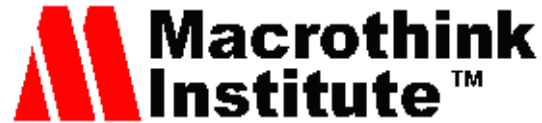

It is different for Brexit, beginning even with the start of the project. The result of the Brexit referendum on June 23, 2016 led to the resignation of British Prime Minister David Cameron. The project was authorised by a majority of voters, but had no project sponsor in the government.

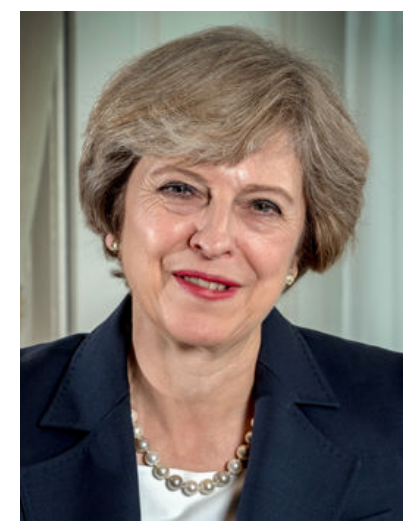

Figure 10. Theresa May; source: Wikimedia Commons/Government of UK

Former Home Secretary Theresa May prevailed within the Tory party and took on the office of Prime Minister on July 13, 2016. Theresa May (fig. 10), who was originally one of the remainers of her party, proclaimed "Brexit means Brexit". What began as the personal confirmation that Brexit would really be implemented has increasingly assumed the character of a hollow phrase as time goes on. The Prime Minister is not making any efforts to reach a cross-party social consensus of the stakeholder groups. A consensus, which would have also demanded conflicting priority judgements, from which she apparently shied away. Instead of reducing the complexity of the overall project, her actions have mainly been aimed at a Tory consensus within the party. For this reason, she also called David Davis, Boris Johnson and Liam Fox to the cabinet, with Michael Gove following.

With the "Lancaster House Speech" on January 17, 2017, the Prime Minister fixed the framework for the impending triggering of Article 50 (May, 2017). The Prime Minister assigned a high level of importance to the question of legal sovereignty. From an economic point of view, she described the aim to be maintaining the greatest possible access to the Common Market with the simultaneous freedom to agree individual trade agreements. The speech also contained the key passage, "[...] no deal for Britain is better than a bad deal for Britain". In other words: The United Kingdom is ready to leave the EU without an agreement. Far before the start of negotiations, this sent a signal of her own strength and determination. However, at the same time, it awakened very high expectations within the country of a "good deal". From the point of view of many Brexiteers, even within the Prime Minister's party, this "good deal" is synonymous with "having my cake and eating it". From this group's point of view, anything else will be a "bad deal", which will be confronted with a hard Brexit after two years without a Brexit agreement and without any agreement for the future.

The "Lancaster House Speech" also highlighted an increasing and yet clearly inadequate 
understanding of the project complexity. The Prime Minister used the term "phased process of implementation" and described the necessary adjustment measures. These are scheduled adjustments as a result of the new agreement with the EU, which the Prime Minister wants to have agreed within the two-year deadline of Article 50. A two-year deadline for the "new agreement with the EU" sub-project, which is in itself highly complex, has to be viewed as unrealistic. With this concept of time, she is ignoring the pertinent experience gained from other trade agreements, especially the CETA free trade agreement with Canada, which required considerably longer periods of negotiation, quite aside from the necessary parliamentary approval of the 27 EU countries. For comparison: The CETA agreement comprises more than 1,500 pages, was negotiated from 2009 to 2016 and was provisionally adopted on September 21, 2017 (European Commission, 2017a, b). The difference to the realistic time frame set by John F. Kennedy for the moon landing project is positively obvious.

On March 29, 2017, the British ambassador in Brussels handed over the letter, with which the Brexit process was triggered in accordance with Article 50 of the Treaty of Lisbon. This legally started the project, on the basis of unresolved conflicts of interest and unrealistic concepts of time.

On April 18, 2017, the Prime Minister announced early parliamentary elections. This was meant to strengthen her position in parliament, especially with regards to the imminent Brexit negotiations. The timing of her high ratings in the polls seemed favourable to build on the comparatively narrow majority in the House of Commons. But contrary to initial expectations, Theresa May actually lost the majority vote in the UK general election on June 8, 2017 and will only be able to govern with the support of the Northern Irish party, the DUP, in the future. This has heavily affected her in her authority as Prime Minister and at the helm of the Brexit project: she did not use the time frame before triggering Article 50 to achieve a comprehensive consensus about the Brexit project aims; she no longer has a parliamentary majority for the top-down establishment of objectives and priorities.

It is becoming increasingly clear that the gap is widening between the complexity of the project and the skills of the organization to handle the project. Although the British government is strengthening in terms of resources, the complexity of the project is drastically increasing as time progresses. Subjects, which could previously still be argued away in abstract terms, like the issue of the border between the Republic of Ireland and Northern Ireland, must now be addressed specifically. In addition, new aspects are arising continually, which represent the proverbial "devil in the detail". Examples of this are the issues of leaving EURATOM, the regulation of flight rights ("open skies") and the preparation for new customs procedures.

In terms of project organization, a further fundamental weakness is becoming obvious. The Prime Minister is acting as the project sponsor but there is no overall Brexit project manager. And that although the head of the civil service, cabinet minister Jeremy Heywood said in July 2017, "This is a classic cross-departmental project, but of unprecedented scope and importance" (Heywood, 2017). 
The necessity of an overall project manager results specifically from the fact that Brexit represents a project portfolio with at least three programs and numerous projects in each program, which urgently require overall optimisation. The three programs are:

1) Departure from the EU and clarification of the future relationships with the EU ("Art. $50 ")$

2) New conclusion of trade deals with non-EU countries

3) Amendment of British law ("Repeal bill")

Without overall project management, a central element of the project management is missing, leading to a high likelihood of problems in terms of apparent conflicts of interest between the subprojects. This is even more apparent now the possible negative effects of an uncoordinated departure from the EU are becoming ever clearer and only limited progress has been made in the negotiations in Brussels.

By proceeding with the project, the possible consequences for the various groups of stakeholders is becoming ever clearer. There are consequences, which are directly dependent on the version of Brexit, about which there is no clarity. As a logical consequence, the stakeholder groups are increasingly attempting to make their voices heard. The conflicts, which should have been clarified at the start of the project, are gaining momentum. And at the same time, despite numerous public statements to the contrary, no systematic analysis was undertaken to get an understanding of the impact of Brexit on the various sectors of the British economy, thus depriving the government of a rational basis for priority setting. During the Parliament Committee meeting on December 6, 2017 David Davis had to admit the non existence of the previously highlighted sector impact assessments: "'There are no systematic impact assessments,' Davis told the panel, to laughter in the room. [..] Asked by Chairman Hilary Benn whether there were analyses of the effects on the automotive industry, aerospace and the financial sector, Davis replied 'no' each time. 'The answer will be no to all of them,' Davis said. He argued that trying to assess the economic impact of Brexit would be pointless. 'When you have a paradigm change, all the models are wrong,' he said" (Hutton \& Morales, 2017).

More than two years after the referendum, there are still fundamental ambiguities about Brexit. The discussions are still ongoing which specific target model should realistically be aimed for in relation to the EU. The cabinet meeting at Chequers (July 6, 2018) was intended to finally come up with a concept that would unify the warring groups. The paper resulting from the Chequers retreat, however, led to the resignation of David Davis and Boris Johnson, thus highlighting the persistent conflicts (HM Government, 2018; Stewart et al., 2018). The ambiguity about the target state is followed by the ambiguity of the path of transformation. It is an ambiguity with far-reaching consequences for all those affected in the United Kingdom and the EU.

\section{Conclusion}

The research questions on the subject of Brexit vs. moon landing have been characterized as 
follows:

1) What kind of complexity framework would be appropriate for a comparison of the two projects?

2) How do Brexit and moon landing compare based on the framework?

3) Can we find a pattern helping to explain why the moon landing was successful whereas the Brexit project seems to be struggling?

ad 1): A complexity framework to be used in the comparison of the two projects has to go beyond the concept of structural complexity. It needs to take into account not only the project challenge per se but also organizational capabilities, perceptions as well as the dynamic character. A four-level complexity framework consisting of (1) objective, (2) relative (3) subjective and (4) dynamic complexity has been suggested for that purpose.

ad 2/3): It will not be possible before 2020 to evaluate the results delivered by the Brexit. But even today, it is obvious that the basic principles of project management are being ignored and that the complexity gap is widening continually. David Davis' quote from June 2017 that the moon landing was simpler than Brexit misses the essential point, as table 4 highlights on the basis of the four complexity levels.

Table 4. Moon landing and Brexit in comparison of complexity levels

\begin{tabular}{|c|c|c|}
\hline & Moon Landing & Brexit \\
\hline $\begin{array}{l}\text { Level 1: } \\
\text { Objective Complexity } \\
\text { (complexity independent from } \\
\text { the organization) }\end{array}$ & $\begin{array}{l}\text { Highly complex technical } \\
\text { project }\end{array}$ & $\begin{array}{l}\text { Highly complex political-legal } \\
\text { project }\end{array}$ \\
\hline Level 2: & Organization: NASA & Organization: Government of UK \\
\hline $\begin{array}{l}\text { Relative Complexity } \\
\text { (capability of the organization } \\
\text { to manage the complexity) }\end{array}$ & $\begin{array}{l}\text { The necessary capabilities are } \\
\text { developed to a basic level, they } \\
\text { are however not sufficient to } \\
\text { reach the project objectives. }\end{array}$ & $\begin{array}{l}\text { The capabilities of the } \\
\text { organization are only developed } \\
\text { to a very rudimentary level; the } \\
\text { organization is taken by surprise. }\end{array}$ \\
\hline $\begin{array}{l}\text { Level 3: } \\
\text { Subjective Complexity } \\
\text { (perception of the project and the own } \\
\text { capabilities of the organization) }\end{array}$ & $\begin{array}{l}\text { The acting individuals show a } \\
\text { clear understanding of the project } \\
\text { challenges and the necessary } \\
\text { advancements of capabilities. }\end{array}$ & $\begin{array}{l}\text { The acting individuals enter into } \\
\text { the project with fundamental } \\
\text { misjudgements: "muddling } \\
\text { through" as a result. }\end{array}$ \\
\hline $\begin{array}{l}\text { Level 4: } \\
\text { Dynamic Complexity } \\
\text { (change of project complexity } \\
\text { and own capabilities over time) }\end{array}$ & $\begin{array}{l}\text { The capabilities are systematically } \\
\text { developed and improved in } \\
\text { accordance with the project plan. } \\
\text { The verification of complexity } \\
\text { handling is based on the sequence } \\
\text { of successful space mission. }\end{array}$ & $\begin{array}{l}\text { The development of capabilities } \\
\text { does not follow a systematic } \\
\text { approach, while at the same time } \\
\text { the complexity of the project } \\
\text { significantly increases. A } \\
\text { top-down-approach in accordance } \\
\text { with professional project } \\
\text { management is not identifiable. }\end{array}$ \\
\hline
\end{tabular}




\section{Macrothink}

Both the moon landing project of the 1960s and the Brexit project of the 2010s/2020, are exceptionally complex projects in their own way. The central difference in terms of project management is that the objective complexity of the project was understood by NASA. This recognition was implemented in a highly professional manner, while forming one of the great moments of project management at the same time. Without John F. Kennedy's clear formulation of the target and the subsequent project management, there would have been no successful moon landing. And precisely this, the clear target setting and the professionalism of the project management, has not been visible in terms of Brexit to date. On July 20, 1969, Neil Armstrong was able to proclaim the moon landing; whether and when the United Kingdom can announce a "Mission Accomplished" for Brexit, and especially in which landing area, is still unclear.

\section{Limitations}

The moon landing is, among others, an astonishing technological accomplishment of global reflection. Therefore, it could be argued if one can consider the moon landing a national "case study" or "project" (as Brexit could be considered), taking into consideration its global impact on humanity.

The moon landing took place under a specific socio-economic and technological background of development which is different from the Brexit preconditions. Thus a comparison and lessons learned are limited by nature.

The process of Brexit as a dynamic phenomenon is still under way. As a consequence no conclusions on the final coutcome of Brexit can be drawn yet. A comparison of Brexit vs. moon landing may provide other insights about managerial and wider socio-economic issues after the finalization of Brexit.

\section{References}

Azim, S. W. (2010). Understanding and Managing Project Complexity. Doctoral Thesis. University of Manchester, Manchester, UK.

Baccarini, D. (1996). The concept of project complexity - a review. International Journal of Project Management, 14(4), 201-204. https://doi.org/10.1016/0263-7863(95)00093-3

Bakhshi, J. et al. (2016): Clarifying the project complexity construct: Past, present and future. International Journal of Project Management, 34(7), 1199-1213. https://doi.org/10.1016/j.ijproman.2016.06.002

BBC. (2017). Davis, David: Brexit 'as complicated as moon landing'. [Online] Available: http://online: bbc.com/news/uk-40420670 (July 26, 2017).

Berg, B. L., \& Lune, H. (2014). Qualitative Research Methods for the Social Science (5th ed.). Harlow: Pearson.

Blanchard, B. S., \& Blyler, J. E. (2016). System Engineering Management (5th ed.). Hoboken, NY: John Wiley \& Sons. 


\section{Macrothink}

Case Studies in Business and Management ISSN 2333-3324 2018, Vol. 5, No. 2

Bosch-Rekveldt, M. et al. (2011). Grasping project complexity in large engineering projects: The TOE (Technical, Organizational and Environmental) Framework. International Journal of Project Management, 29(6), 728-739. https://doi.org/10.1016/j.ijproman.2010.07.00

Bosch-Rekveldt, M. G. C. et al. (2010). The influence of project front end management and project complexity on project success - A contingency approach in project management research. PMI Research \& Education Conference (pp. 1-33). Washington, DC: PMI.

Brady, T., \& Davies, A. (2014). Managing structural and dynamic complexity. Project Management Journal, 45(4), 21-38. https://doi.org/10.1002\%2Fpmj.21434

Collin, R. E. (2008). 'We Choose to Go to the Moon': JFK and the Race for the Moon, 1960-63. Space Times, 47(6), 10-17.

Collins, J. C., \& Porras, J. I. (1994). Built to last: successful habits of visionary companies. New York; NY: Harper Collins.

Davis D. (2016b). Trade deals. Tax cuts. And taking time before triggering Article 50. A Brexit economic strategy for Britain. Conservative Home. July 14, 2016. [Online] Available: http://conservativehome.com/platform/2016/07/david-davis-trade-deals-tax-cuts-and-taking-ti me-before-triggering-article-50-a-brexit-economic-strategy-for-britain.html_ (September 12, 2017).

Davis, D. (2016a). The Economic Case for Brexit. Huffington Post. May 26, 2016. [Online] Available:

http://huffingtonpost.co.uk/david-davis/eu-referendum-brexit-economy_b_10141932.html_ (September 12, 2017).

Dunn, T. N. (2016). 'We'll have our cake and eat it'. The Sun. September 30, 2016. [Online] Available: http://thesun.co.uk/news/1889723 (September 9, 2017).

Dunovic', I. B. et al. (2013). Towards a new model of complexity - the case of large infrastructure projects. 27th IPMA World Congress, Dubrovnik, Croatia. Procedia - Social and Behavioral Sciences. 119. 730-738. https://doi.org/10.1016/j.sbspro.2014.03.082

Edmonds, B. (1999). Syntactic Measures of Complexity. Doctoral Thesis. University of Manchester, Manchester, UK.

European Commission (2017a). EU-Canada trade agreement enters into force. [Online] Available: http://trade.ec.europa.eu/doclib/press/index.cfm?id=1723 (November 19, 2017).

European Commission (2017b). The full text of CETA. [Online] Available: http://trade.ec.europa.eu/doclib/docs/2014/september/tradoc_152806.pdf (November 19, 2017).

European Union (2010). Consolidated versions of the Treaty on European Union and the Treaty on the Functioning of the European Union, Notice No. 2010/C 083/01, Official Journal of the European Union, 53, March 30, 2010.

Flyvbjerg, B. (2005). Design by Deception: The Politics of Megaproject Approval. Harvard 
Design Magazine, 9(22), 50-59.

Flyvbjerg, B. (2011). Case Study. In K. N. Denzin \& Y. S. Lincoln (Eds.), The Sage Handbook of Qualitative Research (4th ed., pp. 301-316). Thousand Oaks, CA: Sage.

Flyvbjerg, B. et al. (2003). Megaprojects and risk: an anatomy of ambition. Cambridge: Cambridge University Press.

Gove, M. (2016). The facts of life say leave: why Britain and Europe will be better off after we leave. [Online] Available: http://de.scribd.com/doc/309694809/Michael-Gove-pro-Brexit-speech (September 9, 2017).

H M Government (2018). Government statement following Cabinet away day at Chequers. 6 July 2018. [Online] Available:

https://assets.publishing.service.gov.uk/government/uploads/system/uploads/attachment_data/ file/723460/CHEQUERS_STATEMENT___FINAL.PDF (July 31, 2018).

Hass, K. B. (2009). Managing Complex Projects: A New Model. Vienna, VA: Managementconcepts.

Henley, J. (2016). Why Vote Leave's $£ 350$ m weekly EU cost claim is wrong. The Guardian. June 10, $2016 . \quad$ [Online] Available: http://theguardian.com/politics/reality-check/2016/may/23/does-the-eu-really-cost-the-uk-350 m-a-week (September 9, 2017).

Heywood, J. (2017). How the Civil Service is preparing for Brexit, Gov.UK, Civil Service. July 11, 2017. [Online] Available: https://civilservice.blog.gov.uk/2017/07/11/how-the-civil-service-is-preparing-for-brexit/ (September 10, 2017).

Hutton, R. \& Morales, A. (2017). Davis Accused of Misleading Parliament Over Brexit Studies, Bloomberg. December 6, 2017. [Online] Available:

http://bloomberg.com/news/articles/2017-12-06/u-k-has-done-no-sector-by-sector-analysis-of -brexit-impact (December 12, 2017). The videorecording of the statement by Davis in front of the Parliament Committee can be found at: Exiting the European Union Committee. Wednesday 6 December 2017. Subject: Department for Exiting the European Union Sectoral Analyses. [Online] Available:

http://parliamentlive.tv/Event/Index/887635ea-6bb5-4b0a-8bf7-3875507a319b (December 12, 2017).

Kumar, J. K. (2016). A study on key factors influencing bid/nobid decisions for different construction projects in India. International Journal of Civil Engineering and Technology, 7(6), 732-737. http://www.iaeme.com/IJCIET/issues.asp?JType=IJCIET\&VType=8\&IType=2

Luo, L. et al. (2017). Investigating the Relationship between Project Complexity and Success in Complex Construction Projects. Journal of Management in Engineering, 33(2), 1-12. https://doi.org/10.1061/(asce)me.1943-5479.0000471

Mance, H. (2016). Britain has had enough of experts, says Gove. Financial Times. June 3, 
2016. [Online] Available: http://ft.com/content/3be49734-29cb-11e6-83e4-abc22d5d108c (September 12, 2017).

May, Th. (2017). Speech by Theresa May, Lancaster House, January 17, 2017. The Telegraph. January $17, \quad 2017 . \quad$ [Online] Available: http://telegraph.co.uk/news/2017/01/17/theresa-mays-brexit-speech-full/ (September 12, 2017).

Maylor, H. et al. (2008). Managerial complexity in project-based operations: a grounded model and its implications for practice. Project Management Journal, 39(1), 15-26.

https://doi.org/10.1002\%2Fpmj.20057

McTague, T. (2017). Liam Fox: Britain does not have capacity to strike trade deals now. Politico. September 4, 2017, update September 6, 2017. [Online] Available: http://politico.eu/article/brexit-trade-negotiations-liam-fox-britain-does-not-have-capacity-tostrike-deals-now/ (September 6, 2017).

NASA (1961). Excerpt from the 'Special Message to the Congress on Urgent National Needs' President John F. Kennedy speaks before a joint session of Congress. May 25, 1961. [Online] Available: https://www.nasa.gov/vision/space/features/jfk_speech_text.html (September 9, 2017).

NASA (2016): NASA Space Science Data Coordinated Archive, Chronology of U.S. Astronaut Missions (1961 - 1972). [Online]. Available: http://nssdc.gsfc.nasa.gov/planetary/chrono_astronaut.html_(April 12, 2016).

National Audit Office (NAO) (2017). Capability in the Civil Service. March 24, 2017. [Online] Available: http://nao.org.uk/press-release/capability-in-the-civil-service/ (September 10, 2017).

Nimmen, J. et al. (1988). NASA Historical Data Book, Volume 1: NASA Resources 1958-1968. Washington, DC: NASA.

Orloff, R. W. (1996). Apollo by the numbers: A statistical reference for the manned phase of Project Apollo. June, $1996 . \quad$ [Online] Available: http://georgetyson.com/files/apollostatistics.pdf (September 12, 2017).

Oswald, A., Köhler, J. \& Schmitt, R. (2018). Project Management at the Edge of Chaos: Social Techniques for Complex Systems. Berlin, Heidelberg: Springer.

Parker, M. (2011). Managing space, organising the sublime. In U. Landfester et al. (Eds.). Humans in Outer Space - Interdisciplinary Perspectives (pp. 28-38). Wien: Springer.

Pasian, B. (Ed.) (2015). Designs, Methods and Practices for Research of Project Management. London: Routledge.

Patzak, G. (1982). Systemtechnik. Heidelberg: Springer.

Public Works and Government Services Canada (2015). Project Complexity and Risk Assessment Manual. Version 5. May 2015. [Online] Available: 
http://tpsgc-pwgsc.gc.ca/biens-property/sngp-npms/pcra-ecrp/risqueproj-riskmnl-eng.html (August 14, 2017).

Ridder, H.-G. (2017). The theory contribution of case study research designs. Business Research, 10(2), 281-305. https://doi.org/10.1007/s40685-017-0045-z

San Cristóbal, J. R. (2017). Complexity in Project Management. International Conference on Project Management / HCist - International Conference on Health and Social Care Information Systems and Technologies, CENTERIS / ProjMAN / HCist 2017. Barcelona, $\begin{array}{lllll}\text { Spain. } \quad \text { Procedia } \quad \text { Computer } & \text { 762-766. }\end{array}$ https://doi.org/10.1016/j.procs.2017.11.098

Seamans Jr., R. C. (2007). Project Apollo: the tough decisions. Washington, DC: NASA.

Shokri-Ghasabeh, M. et al. (2010). "An integrated bid/no bid decision process for construction contractors based on lessons learned", $5^{\text {th }}$ Built Environment Conference, Durban, South Africa, 410-428. [Online] Available: http://www.asocsa.org/documents/proceedings/2010-ASOCSA-5thBE-conference-Durban-R SA.pdf (February 2, 2018)

Singh, A. (2016). Australia seeking free trade deal with UK following Brexit vote. Independent. July $17,2016 . \quad$ [Online] Available: http://independent.co.uk/news/uk/politics/brexit-australia-free-trade-eu-a7141136.html (September 6, 2017).

Stake, R. E. (2000). Case Study. In Denzin, K. N. \& Y. S. Lincoln (Eds.), Handbook of Qualitative Research (2nd ed., pp. 435-454). Thousand Oaks, CA: Sage.

Stewart H. et al. (2018). May's plan 'sticks in the throat', says Boris Johnson as he resigns over Brexit. The Guardian. July 9, 2018. [Online] Available:

https://www.theguardian.com/politics/2018/jul/09/boris-johnson-resigns-as-foreign-secretarybrexit (July 31, 2018).

Turner, J. R., \& Cochrane, R. A. (1993). Goals-and-methods matrix: coping with projects with ill-defined goals and/or methods of achieving them. International Journal of Project Management, 11(2), 93-102. https://doi.org/10.1016/0263-7863(93)90017-H

Vidal, L.-A., \& Marle, F. (2008). Understanding project complexity: implications on project Management. Kybernetes, 37(8), 1094-1110. https://doi.org/10.1108/03684920810884928

Walker, N. (2017). Brexit timeline: events leading to the UK's exit from the European Union. House of Commons Library. Briefing Paper Number CBP-7960. May 2, 2017. [Online] Available: http://researchbriefings.parliament.uk/ResearchBriefing/Summary/CBP-7960 (September 12, 2017).

Williams, T. (2002). Modelling Complex Projects. Chichester: John Wiley \& Sons.

Williams, T. M. (1999). The need for new paradigms for complex projects. International Journal of Project Management, 17(5), 269-273. 


\section{Macrothink \\ Case Studies in Business and Management ISSN 2333-3324 2018, Vol. 5, No. 2}

https://doi.org/10.1016/S0263-7863(98)00047-7

Williamson, D. J. (2011). A correlational study assessing the relationship among information technology project complexity, project complication, and project success. Ph.D. Dissertation. Capella University, Minneapolis, MN.

Wood, W. D. (2011). How Apollo flew to the moon. New York, NY: Springer.

Wynn Jr., D., \& Williams, C. K. (2012). Principles for conducting critical case study research in information systems. MIS Quarterly, 36(3), 787-810.

Yin, R. K. (2009). Case Study Research: Design and Methods. (4th ed.). Thousand Oaks, CA: Sage.

Zhu, J., \& Mostafavi, A. (2017). Discovering complexity and emergent properties in project systems: A new approach to understanding project performance. International Journal of Project Management, 35(1) 1-12. https://doi.org/10.1016/j.ijproman.2016.10.004

\section{Copyright Disclaimer}

Copyright for this article is retained by the author(s), with first publication rights granted to the journal.

This is an open-access article distributed under the terms and conditions of the Creative Commons Attribution license (http://creativecommons.org/licenses/by/4.0/) 